\title{
College English Teaching Reform in China: An Orientation toward ESP
}

\author{
Xingyue $\mathrm{Hao}^{1}$ \& Zhiping Yin ${ }^{1}$ \\ ${ }^{1}$ Faculty of Foreign Languages and Cultures, Kunming University of Science and Technology, Kunming, China \\ Correspondence: Xingyue Hao, Faculty of Foreign Languages and Cultures, Kunming University of Science and \\ Technology, Kunming, 650500 China. Tele: 86-871-151-9880-7142. E-mail: haokust@126.com
}

Received: June 13, 2015 Accepted: June 27, 2015 Online Published: July 14, 2015

doi:10.5430/ijelt.v2n2p77 URL: http://dx.doi.org/10.5430/ijelt.v2n2p77

\begin{abstract}
The teaching of English as a foreign language to non-English majors at the tertiary level in mainland China is referred to as College English. This course has a special position in Chinese higher education because it is meant to equip the future professionals with language skills necessary for international communication, and has therefore attracted large investment of time and money from both the government and individuals involved. Ever since the end of Cultural Revolution and the start of Open-and-Reform Policy, College English teaching in mainland China has gone through four decades of reforms. Interestingly, each round of College English teaching reform lasts for about 10 years, for example, the post-cultural revolution reform from 1976 to 1985, the second stage of reform from the mid 1980s to the mid of 1990s, the third stage is the turn of century reform lasting from the mid 1990s to about 2004, and the fourth stage started from 2004 when the Ministry of Education issued College English Course Teaching Requirement. In recently years, signs of another round of reform are arising as many important journals are publishing papers explaining rationale for the reform. This round of reform is content-driven, characterized by English for Specific Purposes (ESP). Based on this context, we intend to make a brief introduction to the present day College English teaching reform in mainland China. We first introduced the background which includes a survey of the history of the College English teaching reform. Then we made a need analysis from the angles of College English Teaching reform, globalization of economy and internationalization of higher education, particularly the needs of the learners and society in the new era. Both the background and need analyzes help to explain why ESP is going to be the focal point of this reform. Finally, some issues over the terms of English teaching or learning are analyzed, and it finds that the controversies or confusions concerning some concepts like General English (GE) and English for General Purposes (EGP), English for Special Purposes (Esp) and English for Specific Purposes (ESP ) and so on are dwelled upon.
\end{abstract}

Key words: College English, Teaching Reform, English for Specific Purposes, Issues

\section{Background}

The teaching of English to non-English majors at the tertiary level in mainland China is called College English. It is a compulsory course required at the foundation period, i.e., the first two years. It has always been the focus of higher education reform in China not only because it is important for the open-door policy or China's involvement in the internationalization process, but simply it is related to the largest number of people, say, tens of millions of university students. Therefore, expectations of the course from both the society and the government are extremely high, and reform of the course in terms of teaching and education has never ceased. Recently, under the influence of economic globalization and internationalization of higher education, new trends appear in the College English teaching reform.

It is not at all exaggerating to say that no courses have received so much attention as English as a foreign language in Chinese education systems. No better evidence of this statement can be found in such terms as Children English, Junior English, Senior English, College English, Graduate English and so on. This evidently demonstrates that the learning of English runs through a person's whole education life from kindergartens to graduate schools. However, a close examination of what is being taught and learned during those different periods yields no difference in essence in the Englishes taught and learned. Take the course standard or curriculum requirement of English for Senior High School and College English as an example, the most significant difference one can find lies mostly in the amount of vocabulary required of the learners. In English for Senior High School students, the total amount of vocabulary 
required is about 3000 words compared with a vocabulary of about 5000 words in College English. Apart from such requirement differences, the teaching and learning of English in all those periods are more or less the same, that is, skill-driven and examination-oriented. It seems that all that a lower level of English teaching needs to do is to prepare students for the entrance examination into a higher level of English teaching, while all the entrance examinations are no more than testing reading, listening, writing and translating. Even though the teaching and learning of English is skill-driven at all those different levels, and despite the great time and effort from both teachers and students, the average Chinese learners are still far from being skilled in English reading, speaking, listening or writing. This has already led to criticisms swamping into the teaching of English, particularly into the teaching of English at the tertiary level. Therefore, the cries for reform, and indeed, the reform for English teaching in colleges and universities have never been ceased.

Tracing back to the short history of teaching English at the higher education level after the Cultural Revolution in 1976, we can find this interesting phenomenon that the teaching reform has been campaigned at every ten years or so. Before 1985, the teaching of English was focused on the bases of language knowledge, for which the grammar-translation teaching method was adopted, and the English taught was called Basic English or Public English in contrast to English taught as a specialty. From 1985 on, education policy makers perhaps realized that English at the tertiary level should be more than basic English, that is to say, English in colleges and universities should be different from English at primary and secondary levels, because the latter focuses on the bases of English learning. Thus, the term College English was adopted and has been used thereafter. To live up to the term College English, the policy makers made two separate course syllabuses, one for students of liberal arts, and the other for students of science and technology. While the former laid emphasis on the teaching of English for general subjects, the latter laid emphasis on the teaching of English for Science and Technology(EST).

The discipline-driven education reform of English teaching in the mid 1980s was to a great extent like the English for Specific Purposes (ESP) teaching that scholars are promoting today. However, the implementation of College English Test Band 4 (CET-4) and Band 6 (CET-6) in 1987 and 1988 has changed the direction of this reform. In around 1995, the two separate College English syllabuses for different disciplines were again merged into one. The reason for such a change can be found in the prevalence of CET-4 and CET-6, both of which examine language skills rather than content mastery. This has put an end to the practice of discipline-based English language teaching. Though widely criticized, the CET-driven teaching has been lasting for quite a while into the $21^{\text {st }}$ century until 2004 when the Ministry of Education issued the College English Course Teaching Requirement which signaled another campaign of College English teaching reform. However, this reform has been mainly centered around the teaching models, for which the computer-aided teaching, internet based learning, learner-centered teaching, and autonomous learning approaches and so on are proposed. Its focal purpose is apparently to solve the problems of large class sizes resulting from the popularization of higher education since the end of last century. Now this round of reform has been here for about another ten years, in which tides of cries for further reform rise one after another. We are not prophets, but the status quo has made it clear that the coming years after 2015 will certainly see another campaign for College English teaching reform, and it seems certain that this reform will be focused on the content of College English, and most probably it will be English for Specific Purposes.

\section{Why the Reform?}

The reason why this new round of college English teaching reform will be content-driven, and it will be English for Specific Purposes are as follows. First of all, four decades of college English teaching reform has paved the way for Chinese College English Teaching to move to a higher level, that is, from General English teaching to teaching English for practical uses like academic, vocational, cultural and social communications (Qin 2003, Zang 2003, Cai 2004, Su 2004, Lu 2010, Yang 2010, Hu 2011). Secondly, the globalization of economy and internationalization of Chinese higher education institutions call for teaching English for Specific Purposes so that Chinese university students are linguistically prepared to take part in international activities or are prepared to communicate their special fields with international people after they exit the higher education institutions. Thirdly, the diversification of needs on both the students' and societal sides requires teaching English not only for general purposes but also for specific individual needs.

\subsection{The Needs of the College English Teaching Reform}

Four decades of College English teaching has been mostly General English (GE) teaching. By GE, we mean English for ordinary communications. Therefore, GE teaching focuses on basic communication skills. To achieve such a purpose, teachers have to teach such basic linguistic knowledge as grammar, vocabulary, syntactic structures, 
semantic meanings, discourse analysis and so on. Both teachers and learners have to spend all the time and effort practicing listening, speaking, reading, writing and translating skills, as the term GE suggests, in general affairs, rather than in specific areas. Though it is nothing wrong to teach these knowledge or skills, the repetition of all the same things at the tertiary level is not only a waste of time and effort on both sides of the teachers and learners, but also a waste of students' intelligence(Cai 2012). Why a waste? In recent years, Chinese students start learning English at the primary level when they are about nine years old. Some even earlier, in the kindergarten when they are about three years old or so. Since then, they have been learning vocabulary and grammar, practicing listening, speaking, reading, writing and translating all the way through junior high school and senior high school until they finally land in universities or colleges. The repetition of the same things that they have been learning for about ten years before they come to the universities will definitely make them bored. The loss of interest or motivation for learning English is demonstrated once they pass CET-4 or CET-6 and stop learning or practicing English. The problem is that some students pass CET-4 or CET-6 very earlier in the first term or second term, and the earlier they pass the CET, the earlier they cease the learning, the more they forget about the basic knowledge of English language. That is one of the main reasons why they complain that they are poorer in English in universities than in high schools (Zhao et al.2009). Obviously, they want more than GE or CET-4, and a lot of researches (Yang 2010, Huang et al. 2011, Cai 2012) have demonstrated that what students need most earnestly on the tertiary level is not the basic knowledge from General English, but something related to what they are specializing in colleges and what they are going to do in their future careers.

So why has GE been in the tertiary institutions for about 40 years? In the first decade from 1976 to 1985, the Chinese higher education went through a revival period in which everything started from the very beginning. My own higher education experience as an English major in the early 1980s is a good case in point. I remember that we started the university by learning the most basic language knowledge like phonemes, alphabets, grammar, sentence patterns and so forth usually by drilling, obviously under the influences of structuralism. The reason for this is that before we went to the university we had learned English for about only two or three years in senior high school. This makes it reasonable for the higher education institutions to adopt a curriculum that laid emphasis on learning the basic knowledge of a foreign language. Even so, in the mid-1980s, the implementation of two separate English teaching syllabuses, as mentioned above, saw some hints of discipline-driven or ESP teaching. However, this did not last long mainly because university students at that time did not have a very sound basis or sufficient general knowledge of English for the discipline-driven teaching. The emergence of CET in the mid 1980s which stressed the basic knowledge was a good answer to this problem. The teaching of English since then became so centered on GE that the two separate curricula were no longer necessary and they were incorporated into one again a decade later in the mid 1990s. Indeed, from the second decade on, the CET-4 driven and examination-oriented English teaching has become so influential that nothing but GE is taught and learned in most Chinese higher education institutions.

However, if GE in universities was reasonable for the past four decades, the continuation of GE in the coming new decade seems to be not only out of step, but also a hindrance to the development of Chinese higher education. Forty years ago, students had only learned English for only two or three years before they went to universities; forty years later, they have learned English for about ten years before they enter colleges or universities. The curriculum criteria for Senior High School in the 1980s and 1990s required graduates of a vocabulary of about 1800 words, while the New Course Standard in the first decade of the $21^{\text {st }}$ century has increased the vocabulary to 3500 words (Huang 2009). Comparing with the College English Course Requirement in 2004, which sets a vocabulary of 4500 words, it does not suggest a great discrepancy between high school English teaching and college English teaching in terms of GE. As a matter of fact, many secondary school graduates are equipped with more than 4000 words upon their arrival at the universities, particularly, the 211- or 985-project universities, as the Criterion of the Ninth Level for Senior High School graduates has increased the vocabulary to 4500 . These students can easily pass CET-4 and get a very high score just in the first term in college. Apparently, they expect something more than GE. They want to learn something that could meet their specific individual needs, which seem to lie in ESP.

\subsection{Requirement of Globalization and Internationalization of Higher Education}

More and more people in China have come to realize that the globalization of the $21^{\text {st }}$ century has made English a lingua franca not only in the area of economy, but also in international communications. There have been numerous statistical evidences that show how English is widely used in media, publication, international conferences, scientific research and so on. The English language has become so globalized that some Chinese scholars even claim that English should not be treated as a foreign language. Indeed, English as a school subject has achieved the same important status as the other Chinese school disciplines. A good case in point of this can be found in the Iron Triangle of Chinese, Mathematics and English throughout the Chinese primary and secondary schools. As a matter of fact, 
English has become even more important than the other two subjects in terms of the time and effort spend on it, because it is the only subject that extends into the students' lives at the tertiary level. Even though so much time and effort are spent and so much importance is attached to it, it is not as enabling as it should have been like the other school disciplines, for a great number of students can not follow the bilingual teaching in their own specialty, not to mention the subject courses taught solely in English.

The so-called bilingual teaching in the Chinese context or teaching special subjects in English has become a new trend in Chinese universities since the start of the $21^{\text {st }}$ century when the Ministry of Education decides that Chinese higher education should also participate in the internationalization process. The aim of this is not only to prepare Chinese talents to participate professionally in the international affairs, but also to attract international students to study subject courses in Chinese universities. However, except that some top universities of the 985-Project can offer some programs successfully in English, most are not very successful. According to my colleague's research (Che 2004) funded by the National Social Sciences Foundation, bilingual teaching fails to achieve its purposes in that students do not learn very well in terms of either their subject courses nor the English language. The reason for this is that students are not proficient in using English to deal with academic matters so that bilingual teachers have to lower the difficulty level of the subject content, which is obviously not up to the standard required by the curriculum. Another reason for such a failure is perhaps because the bilingual teachers, usually the subject matter teachers, are not proficient in teaching in English. Therefore, if bilingual teaching or teaching subject courses in English is a must for the internationalization of Chinese higher education, College English that focuses on teaching general English language skills will have to be reformed. It should move from skills to content, or from GE to ESP so as to prepare students not only for bilingual subject courses but also for their future professional careers.

\subsection{The Needs of Learners and Society}

The rationale for ESP teaching instead of GE teaching at the tertiary level can be justified by a discussion of the needs from both sides of learners and society. Theoretically, need has been studied from many different angles. The most typical studies on needs can by found in Richards (1984) who classified needs into objective and subjective needs and Hutchinson \& Waters (2002) who analyzed needs from the perspectives of situational target and learning. Whether it is Richards' objective need or Hutchinson \& Waters' situational target need, this need is to satisfy the requirement of the society. Likewise, whether it is subjective need or learning need, such kind of need is to satisfy the individual learner's own need. Therefore, some Chinese scholars like Su (2004) and Zhang (2010) have made need analysis more straightforward: the social need and the individual learner need. The so-called social need is the necessity for practical knowledge and skills of the foreign language that a society needs for its development, whereas the individual learner's need refers to the differences between the learner's present level and the level he wants to achieve for his own individual development. This classification of needs coincides with the aim of higher education which seeks to satisfy both the individual learner's and societal needs for their respective development.

Then, what are the individual learners' needs and society needs in terms of English learning and teaching? The answers to this question can only be found by practical investigations which have been carried out by many a researcher since 1980s to the present moment. Some of the most influential researches into the needs are done by Cheng (1984) from the Shanghai Jiaotong University, Ying (1996)from the Zhejiang University, Xia and Yan (2003) from the Chongqin University. In recent years, more scholars like Cai (2010) from Fudan University and Hu et. al. (2011) from Anhui University have implemented more up-to-date studies of English learning need in relation to the society development. In more general terms, all these studies suggest that the teaching and learning of a foreign language is to meet the society's need to learn from the foreign advanced science and technology, to engage in international academic and cultural exchange, to promote its participation in the international business and trade activities and so on. But when specific organizations are concerned, their needs become more practical. Cai's research (2010) in the Shanghai area in 2009 demonstrates that over $90 \%$ of the organizations require not only the general competence in listening, speaking, reading and writing but particularly an immediate ability to use the foreign language to handle their special tasks at work. Hu's research (2011) has similar findings in which about $80 \%$ of the responses indicate that the organizations need foreign language skills and knowledge related to the organization's practical business or industry.

Compared with the societal needs, the individual learners' needs are more apparent and can be directly felt by teachers and researchers alike. If it is true to say that some learners learn English in order to go to the English speaking countries for immigration, for work or for further studies, it is more true to say that most learners will have to work and live in China. So the first and foremost need they have to satisfy is the societal need, and the most direct and urgent need they have to meet is the more and more popular bilingual subject courses or specialty courses 
completely taught in English. To succeed in these courses, a bridging course has become increasingly urgent. This course seems to be English for Specific Purposes as suggested by Yang (2010) that Chinese learners' major purpose of English learning is to be able to use English as a tool to obtain information in their special field and to express their special ideas in English.

\section{Is the ESP-driven Reform Feasible?}

In the previous parts of the article, we have explored the histories and needs of College English teaching reform in mainland China, and have suggested that the coming years will witness a new decade of College English teaching reform. This new round of reform will very likely be content-based or discipline-driven teaching reform, that is to say, a reform leading towards teaching English for Specific Purposes. But is ESP feasible? For this question, an investigation into the true nature of ESP can show some hints.

\subsection{The Earlier View of ESP and Its Failure}

English for Specific Purposes was first put forward in the 1960s and 1970s in the western countries (Barber 1962, Halliday 1964, Herbert 1965, Ewer\& Latorre 1969) on the principle that English was becoming a lingua franca in economy, science and technology, and culture exchanges, and that linguistic research focus was shifting from language usages, i.e, language systems to practical language uses (Wang 2012). This idea had a strong impact on the foreign language teaching in China in the 1980s when a variety of ESP courses such as English for Metallurgy, English for Medicine, or English for Hydropower and so on were put on the shoulders of the college English teachers. Therefore, as mentioned earlier, in the mid-1980s two different College English Teaching Syllabuses came into being, one for Liberal Arts (1985) and the other for Science and Technology (1986).

However, this trend of discipline-based teaching reform or the so-called ESP teaching was not very successful and did not last long. There are three reasons related to this failure. One is that the implementation of CET- $4 / 6$ focused on the general language skills and the tested materials are mainly humanities, which obviously eradicated the need for ESP. The second reason is the perspective that people adopted for ESP, which was associated with courses and coursebooks like English for Chemical Engineering, English for Mining, to name just a few. The fact that those courses were too preoccupied with teaching the subject content rather than the language made it far beyond the reach of the language teachers whose education background was mainly of humanities. The third reason which can never be neglected is that students in the mid 1980s were not linguistically, to be more exact, grammatically or syntactically prepared to take subject-based English courses when they were still so poor in basic language knowledge as we have mentioned above. Thus the cries from both teachers and some famous domestic scholars (Dong 1986, Yang 1994) for GE to enhance the students' language bases, together with the implementation of CET-4/6, quickly put an end to the earlier attempt of ESP in College English, and the emergence of the two separate syllabuses into one College English Teaching Syllabus in the mid 1990s signaled the complete failure of ESP endeavor in the $1980 \mathrm{~s}$.

\subsection{The Present View of ESP and Its Revival}

The earlier view of ESP was content driven, that is, the teaching of the content was regarded as an end while the teaching of the language as a means. That is perhaps why ESP was regarded as unteachable by English language teachers who are pro-humanities, and unlearnable by students who were poor in basic language knowledge. Presently, people have come to view ESP just the other way round. They regard the teaching of the content as a means, and still the language as the end with some orientation towards the content. The change of view that ESP is a course not oriented toward any particular subject, but toward the commonness of different subjects is shared by scholars at home and abroad (Hutchinson \& Waters 1987, Dudley-Evans \& St John 1998, Cai 2013). Obviously, this change makes ESP sound more friendly to both teachers and students alike. To teachers, they can teach the common cores of language with orientation towards academic or occupational matters; to students, they can learn something that can help them deal with their subjects or future careers better in the target language. Mostly importantly, it complies with the present trend of College English teaching reform, which used to be more or less confused with its efficiency and efficacy. Thus, a revival of ESP on the tertiary level is obvious as it can be shown in so many journal articles intending to explore the theoretical and practical feasibilities from a variety of perspectives, and can be demonstrated by the reduction of GE and increase of content-based courses in many universities' teaching programs. Apparently, it is this change of perspectives of ESP that makes the reform possible. 


\section{What Is the Reform Like?}

While the revival of ESP seems inevitable in the present college English teaching reform, its failure in the 1980s can not be overlooked. With theories like student-centeredness, autonomous learning, constructivism and humanism playing dominant roles in the present-day foreign language teaching, the approach to ESP will have to be cautious, and the implantation of ESP at the tertiary level in mainland China will have to take learners and society into consideration. As for the learners, their needs are the first and foremost factor that will influence what is going to be taught. Even though many students have the immediate need for a bridging course between GE and bilingual teaching in the university days, and that they are going to use English to handle specialty-related affairs in their future careers, yet that is not conclusive.

As China is so big and students are so populous, students' needs are going to be diversified. Some students need English desperately because they want to go abroad or use English in their future careers, but others may not need English at all. What they need is just to pass the required tests in order to exit smoothly from the schools. Similarly, the society is a complex body made up of different communities in which all sorts of talents are needed. It needs not only people with professional skills like scientists and engineers to whom ESP might be a must, but also people of high cultural and humanistic quality like government servants and social workers to whom English as Liberal Education (ELE) might be more practical. Furthermore, the classification of Chinese higher education institutions into different levels will make the nation-wide implementation of ESP difficult. Key and prestigious universities of the 985-project or 211-project take in the best students provided by the highly selective College Entrance Examinations. Those students with a score well above 120 out of a total of 150 in the English Matriculation Test (or English for College Entrance Exam) have had a sound basis in GE. They are more ready for a subject-based English course in universities which offer the most bilingual programs or all-English teaching subject courses. Comparatively, local non-key institutions will have to admit students whose English score is just around 90 or even far below that. The students' poor foundation in GE in these institutions will make it hard for them to follow a foreign language course with subject orientations. This indicates that GE to a certain extent is still necessary for some of them before they move on to ESP.

For the above reasons, a little adjustment is advisable to the widely advocated idea that ESP is made up of English for Academic Purposes and English for Occupational Purposes (Hutchinson \& Waters 1987, Cai 2011). ESP should be more than that. It should live up to the needs of the society, particularly the needs of the individual learners. For the sake of this, it seems that English for Specific Individualized Needs (ESIP) would be more appropriate. The ESIP is a series of courses made up of General English (GE), English for General Academic Purposes (EGAP) (Jordan 1997, Sun 2011), English for Special Academic Purposes (ESAP) (Jordan 1997), English for Occupational Purposes(EOP) and English for Liberal Education(ELE)(Wang et al. 2011). The ESIP is basically ESP but more inclusive with the addition of GE and ELE. Thus, a tentative design of College English syllabus for the undergraduates is presented below:

Table 1. A Tentative Design of College English Courses

\begin{tabular}{|c|c|c|c|c|}
\hline \multicolumn{2}{|c|}{ Year 1} & \multicolumn{2}{|c|}{ Year 2} & Years 3 or Year 4 \\
\hline Term 1 & GE/EGAP & Term 3 & ESAP & $\begin{array}{l}\text { ELE: Courses such as Western History, } \\
\text { philosophy, arts, literature, etc. }\end{array}$ \\
\hline Term 2 & EGAP & Term 4 & EOP & \\
\hline
\end{tabular}

From the table above, it can be seen that most of the courses are arranged in the first two years because as mentioned above ESP courses serve as a bridge between GE and bilingual teaching or whole-English teaching of subject courses in Year 3 and Year 4. The reason GE or EGAP is put in the first term is to make it optional. For students of lower English levels in those local or non-key higher education institutions, GE which focuses on listening, speaking, reading and writing, might still be necessary. For students of higher English levels in 985-project or 211-project universities, they can take EGAP courses right from the first term on. The discipline-driven EGAP courses consist of two main categories, namely, English for Science and Technology and English for Liberal Arts. This idea of EGAP is very much like the curriculum adopted in the mid-1980s. Its purpose is to help students cope with general academic linguistic features like vocabulary, grammar, writing styles and so on. However, the ESAP programs in the third term should be more specialized than EGAP. The EOP, moves a step further toward students' special area, and can serve 
as a direct transition toward bilingual teaching or whole-English teaching of subject matters in the third or fourth year.

The reason ELE is arranged in the third or fourth year is to maintain the students' interest in English learning by offering courses like English speaking countries' history, geography, humanities, literature, poetry, films and so on. The aim of it is on the one hand strike a balance between English for Specific Purposes and English for General Purposes, and on the other hand can meet the need to improve students' quality in humanities and literature stipulated by the quality-oriented education proposals.

\section{Issues to Be Solved}

Though the reform seems feasible, yet there remain some problems. These problems arise from confusions about some concepts related to College English teaching reform in the Chinese context.

As mentioned earlier, the teaching of English in college has become so conceptualized that many people have assumed that College English on the tertiary level refers only to teaching English to non-English major students. In order to make it different from the English taught to English majors, different terms like Basic English, General English and Public English have been used in the past four decades. Perhaps in order to make the concept of Basic English or General English different from the Primary School English or Secondary School English which are of course basic, the term College English hence came into being and has been so conceptualized that many teachers and students would not like to spend a minute thinking in what way it is different from basic or general English.

Then, is College English at the tertiary level General English(GE) or English for General Purpose (EGP)? From the journal articles in mainland China we have found that some scholars use them interchangeably, seemingly making no differences in them. But when we put them into Chinese, the differences become self-manifest. GE in Chinese is Putong Yingyu, which means something like common English or everyday English, obviously lacking in academic features, while EGP, Tongyong Yingyu in Chinese, which means universal English, suggesting the kind of English that can be used universally in almost every field. This Chinese implication of being universal is perhaps another hidden reason that made the Chinese educators give up ESP in the 1980s and believed what they taught and learned was EGP. However, a glimpse of the courses offered in the College English classes fails to let us see many differences from what is being taught and learned in elementary and secondary schools. All these institutions of the different levels are preoccupied with the kind of listening, speaking, reading, writing and translating for the sake of getting good scores in examinations, which focus only on ordinary matters, and which is nothing but GE.(Zang 2003) Despite the great deal of time and efforts, many people are still poor in using English to solve their professional problems. This means that the College English is not EGP because it is not universal at all. The College English is at most GE, because it still focuses on the basis of language learning.

Fortunately, some scholars have begun to see the differences and they become very careful in choosing the term GE or EGP. The occasions in which GE is referred to as Putong Yingyu and EGP as Tongyong Yingyu are becoming more and more in the Chinese journal articles. For example, Zhang (2010) deliberately used EGP as Tongyong Yingyu rather than Putong Yingyu when he was attempting to classify the English Specialty into two majors: English for General Purposes and English Language and Literature. Take Professor Cai as another example, he avoided the term EGP and used the term GE to refer to Putong Yingyu. We believe that he sees the differences between the two terms. And this perhaps becomes one of his rationales for advocating ESP in College English. Therefore, to live up to the term College English, what is to offer to the students should be more than ordinary and general, and should be something that is different from or more advanced than what they have learned previously in secondary or primary schools.

Apart from the confusion about GE and EGP, there is also confusion about the concept of ESP. Is it English for Special Purposes or English for Specific Purposes? Are they different or are they the same thing? The Chinese equivalents Zhuan Ye Ying Yu or Zhuan Men Yong Tu Ying Yu seem to suggest that they are different. However, many journal articals or even important document referring it to Zhuan Ye Ying Yu or Zhuan Men Yong Tu Ying Yu interchangeably seem to suggest that they are the same thing. For one example, in her paper, A Study of ESP Textbook English for the Arts (Guo, 2011), the author alternately uses the terms Zhuan Ye Ying Yu and Zhuan Men Yong Tu Ying $Y u$ obviously referring to ESP as the same concept. For another, the 1998 version of National College English Syllabus referred to subject-based English, i.e. Zhuan Ye Ying Yu as English for Special Purposes and stipulated that it should be taught in the junior or senior year by teachers from special fields rather than by teachers of College English. This is obviously different from today's Zhuan Men Yong Tu Ying Yu or English for Specific Purposes, which 
is supposed to be within the reach of college English teachers because its focus is on the language as its end and content only as a means to reach this end. Today's dominant idea of ESP consisting of EAP and EOP is becoming increasingly accepted as Zhuan Men Yong Tu Ying Yu.

Obviously, such confusions about the concept of ESP will certainly hinder its smooth implementation in College English. First of all, the concept of ESP as Zhuan Ye Ying Yu will give a good excuse for College English teachers to stick to GE in the name of EGP, for Zhuan Ye Ying $Y u$ is far beyond their educational background and should be taught by teachers from the special fields. Secondly, no better example can be found in the failure of ESP in the 1980s and 1990s, the reason for which as we have mentioned is too subject-oriented. Thus, we would like to propose Zhuan Men Yong Tu Ying Yu for English as Specific Purposes, shortened as ESP, and Zhuan Ye Ying Yu for English for Special Purposes, shortened as Esp, so as to distinguish from English for Specific Purposes.

\section{Conclusion}

The teaching of English at the tertiary level in mainland China has become conceptualized for decades as the teaching of College English. It is so conceptualized that many teachers and researchers have taken it for granted that it is no more than the routine teaching of reading, writing, listening and speaking. Evidence of this can be found in a glance at the English courses taught in colleges and universities and the items tested in CET-4 and CET-6. Many a teacher and researcher have failed or reluctant to reflect upon what should be taught in College English until recently when a new tide of College English teaching reform is on the agenda. In this transitional period, some argue that college English teaching should be content-based rather than skill-driven; others hold that College English teaching belongs to the humanity category, where courses like western literature, cultures and philosophy should be taught. There are still many others believing in the general purposes of English in all the fields maintain that College English teaching be focused on its communicative functions.

Drawing the above status quo as the context of research, we have reflected upon the history of mainland College English Teaching reform and found out that each tide of College English Teaching reform lasts for about ten years and the coming years will see another wave of reform. We believe that this new decade of reform will be content-oriented because enabling students to communicate their special areas with foreign counterparts not only meets the needs of College English teaching reform, but also the needs of globalization of economy and internationalization of higher education, particularly the needs of the learners and society as well. To achieve these aims, College English should be ESP rather than General English or English for General Purposes. Then we made a research into the true nature of ESP from different perspectives. Based on these analyses, we propose a tentative new idea for ESP, i.e. ESIP, making it more inclusive so that it can comply better with the Chinese higher education situations. Finally, we explored the confusions about such concepts as GE, EGP, ESP or Esp, hoping that the clarifications of misconceptions will smoothen the way for the upcoming College English Teaching reform.

\section{References}

Barber, C. (1962). Some measurable characteristics of modem scientific prose. In F. Behre (Ed.), Contributions to English syntax and Philology (pp. 21-43). Gothenburg, Sweden: Almqvist and Wiksell.

Cai, J. G. (2004). ESP and development direction of College English teaching in China. Foreign Language World, 2, $22-28$.

Cai, J. G. (2010). An analysis of factors prohibiting the transformation of College English teaching in China. Foreign Languages Research, 2, 40-45. http://dx.doi.org/10.13978/j.cnki.wyyj.2010.02.023

Cai, J. G. (2010). Reflections on the repositioning of College English Teaching in China. Foreign Language Teaching and Research, 42(4), 306-308.

Cai, J. G. (2012). A curriculum reform for English majors in the transition period of College English teaching reform. Foreign Languages in China, 45(1), 10-15. http://dx.doi.org/10.13564/j.cnki.issn.1672-9382.2012.01.011

Che, Y. P. (2004). Causes of failure of bilingual teaching in the classroom environment in Southwest China. Unpublished research report.

Dong, Y. F. (1986). Editing principles and guidelines for the trial version of College English. Foreign Language World, 23(4), 20-24.

Dudley-Evans, T. M., St. John. (1998). Development in English for Specific Purposes. Cambridge: Cambridge 
University Press.

Ewer, J. R., \& Latorre, G.. (1969). A Course in Basic Scientific English. New York: Longman.

Guo, Y. L. (2011). Editing principles and features of Art's English. Foreign Languages in China, 8(1), 85-89. http://dx.doi.org/10.13564/j.cnki.issn.1672-9382.2011.01.014

Halliday, M. A. K., McIntosh, A. \& Strevens, P. (1964). The Linguistic Sciences and Language Teaching. London: Longman.

Herbert, A. L. (1965). The Structure of Technical English (pp. 1-4). London: Longman.

Hu, W. Z. (2011). An address made at the Opening Ceremony of the ESP Committee of the Chinese Foreign Language Teaching and Research Society. Beijing: Foreign Language Teaching and Research Press, May 7.

$\mathrm{Hu}, \mathrm{X} . W$. et al. (2011). Analysis of social needs for College English. Foreign Languages in China, 8(5), 12-17. http://dx.doi.org/10.3969/j.issn.1672-9382.2011.05.003

Huang, L. S. (2009 June 22). Emphasis laid on vocabulary in the Matriculation English Test after the New Curriculum Reform. $21^{\text {st }}$ Century English Education Weekly.

Huang, P., \& F. Guo. (2011). Trend in College English teaching, EGP or ESP: an empirical study of discourse needs in the international logistics service. Foreign Languages Research, 129(5), 22-27. http://dx.doi.org/10.13978/j.cnki.wyyj.2011.05.020

Hutchinson, T., \& Waters, A. (1987). English for Specific Purposes: A Learning-centered Approach. Cambridge: Cambridge University Press.

Hutchinson, T., \& Waters, A. (2002). English for Specific Purposes. Shanghai: Shanghai Foreign Language Education Press.

Jordan, R. R. (1997). English for Academic Purposes. Cambridge: Cambridge University Press.

Liu, R. Q. (1996). English language teaching in the $21^{\text {st }}$ century: a survey in Great Britain. Foreign Language Teaching and Research, 106(2), 1-9

Qin, X. B. (2003). The Nature, Scope and Principles of ESP Teaching--An Inquiry into the Feasibility of Initiating Various English Teaching Programs in China's Institutions of Higher Learning. Journal of South China $\begin{array}{llllll}\text { University of Technology (Social } & \text { Science }\end{array}$ http://dx.doi.org/10.3969/j.issn.1009-055X.2003.04.016

Richards, J. C. (1984). Language curriculum development. RELC Journal, 15(1), 1-29. http://dx.doi.org/10.1177/003368828401500101

$\mathrm{Su}$, D. F. (2004). Foreign Language Teaching Reform: Issues and Countermeasure. Shanghai: Shanghai Foreign Language Education Press.

Sun, Y. Z., L. W., Li. (2011). CBI and ESP versus directions of reform in English majors and College English teaching in China. Foreign Language Research, 129(5), 1-4. http://dx.doi.org/10.13978/j.cnki.wyyj.2011.05.016

The PRC Ministry of Education. (2003). Curriculum Standard for Senior English (trial version). Beijing: People's Education Press.

The PRC Ministry of Education. (2000). Full Time Secondary School English Teaching Curriculum (revised). Beijing: People's Education Press.

Wang, S. R. et al. (2011). A survey of the status quo of College English Teaching in China and its direction of reform and development. Foreign Languages in China, 43(5), 4-11. http://dx.doi.org/10.13564/j.cnki.issn.1672-9382.2011.05.011

Wang, L. (2012). Status quo and tendency of 50 years of ESP research: a review of New Directions in ESP Research. Foreign Language World, 6. 90-94.

Xia, C.Y. et al. (2003). Social needs and College English teaching reform. Journal of Chongqing University (Social Sciences Edition), 9(6), 57-59.

Yang, F. J. (1994). Learning English and enjoying the entirety of beauty. Foreign Language World, 2, 1-2.

Yang, H. Z. (2010). EAP in China: yesterday, today and tomorrow. Forum for Chinese ESP Summit. Beijing: Beijing Foreign Studies University. 
Ying, H. L. (1996). Theoretical foundations and social bases for the curriculum design. Foreign Language World, 2 , 41-45.

Zang, Z. B. (2003). Another perspective of foreign language teaching reform in China. Foreign Languages, 4. 1-6.

Zhang, C. (2010). Thoughts of reform in English subjects and majors: normalization and standardization. Foreign Language Teaching and Research, 42(4), 309-311.

Zhang, S. J. (2010). Training of talents with solid foundation, strong capability and high quality for the plural needs of the society: a reflection upon the teaching and education reform for English majors. Foreign Languages in China, 3, 4-9. http://dx.doi.org/10.13564/j.cnki.issn.1672-9382.2010.03.016

Zhao, Q. H., et al. (2009). College English teaching in the perspectives of English learners' needs. Foreign Language World, 4, 14-22. 